\title{
Rancang Bangun Sistem Informasi Posbakum Pada Pengadilan Agama Serang Mengguanakan GIS ( geografis information sistem ) berbasis website.
}

\author{
Sarmuni ${ }^{1}$ \\ ${ }^{I}$ Program Studi Informasi, Fakultas Teknologi Informasi- Universitas Serang Raya \\ Jl. Raya Cilegon - Serang Km.5 Taman Drangong Kota serang - Banten, indonesia \\ ${ }^{1}$ Sarmuni010@gmail.com
}

\begin{abstract}
Posbakum merupakan Pos Bantuan Hukum yang berfungsi Pemberian jasa bantuan hukum yang difasilitasi oleh negara melalui PA/Mahkamah Syar'iyah yang bertugas memberi bantuan hukum secara Cuma-Cuma bagi masyarakat pencari keadilan yang tidak mampu. Dalam proses peradilan perdata, baik yang menyangkut hukum materil dan formil, dikenal asas-asas yang bertujuan untuk melindungi kepentingan hukum dari para pihak (penggugat dan tergugat) yang berperkara di Pengadilan Agama. Analisis yang dilakukan adalah mempelajari sejumlah informasi dalam penanganan suatu masalah yang dikhususkan pada kegiatan hukum dan memetakan berbagai jenis informasi yang ada terhadap fungsi sistem informasi atau personil yang bertanggung jawab menyediakan dan juga mengakses informasi tersebut. Metode yang digunakan adalah studi kasus yang dilakukan di Pengadilan Agama Serang. Pengolahan data dilakukan dengan menggunakan alat Sistem Informasi POSBAKUM (Pos Bantuan Hukum) menggunakan GIS (Geografis Information Sistem). Sehingga akan dapat dikembangkan suatu system informasi yang berbasis komputer untuk mendukung penanganan berbagai permasalahan pada bidang peradilan.
\end{abstract}

Kata kunci: Sistem , Informasi, GIS, POSBAKUM, Hukum.

\section{LATAR BELAKANG}

Dalam kehidupan kita di masa saat ini, teknologi informasi dan telekomunikasi merupakan sektor yang paling dominan. Berkembangnya teknologi dan informasi akan menyebabkan semakin kompleksnya kebutuhan akan informasi dan pengolahan informasi, sehingga kebutuhan penggunaan beberapa jaringan komputer secara bersamaan sangat diperlukan. Penggunaan jaringan komputer secara bersama ini tumbuh dan membentuk sebuah jaringan komputer yang sangat besar dan tersebar diseluruh bagian dunia.

Jaringan komputer yang sangat besarini kita kenal dengan nama internet. Internet bisa diakses dan dimanfaatkan untuk berbagai macam keperluan akan informasi. Sesuai dengan perkembangan jaman pula teknologi internet pun semakin berkembang dan beragam. Dengan kemampuannya yang seperti ini web menjadi semakin terkenal dan perkembangannya pun sangat pesat.
Posbakum merupakan Pos Bantuan Hukum yang berfungsi Pemberian jasa bantuan hukum yang difasilitasi oleh negara melalui PA/Mahkamah Syar'iyah yang bertugas memberi bantuan hukum secara Cuma-Cuma bagi masyarakat pencari keadilan yang tidak mampu. Dalam proses peradilan perdata, baik yang menyangkut hukum materil dan formil, dikenal asas-asas yang bertujuan untuk melindungi kepentingan hukum dari para pihak (penggugat dan tergugat) yang berperkara di Pengadilan Agama. Adapun asas-asas hukum tersebut antara lain adalah sebagai berikut :

Bahwa UU Nomor 4 Tahun 2004 tentang Kekuasaan Kehakiman menganut asas peradilan berbiaya ringan dan asas persamaan perlakuan terhadap pihak-pihak yang berperkara, yaitu: Pengadilan mengadili menurut hukum dengan tidak membedakan orang (Pasal 5 ayat 1). Pengadilan membantu pencari keadilan dan berusaha mengatasi segala hambatan dan rintangan untuk dapat tercapainya peradilan yang sederhana, cepat, dan biaya ringan (Pasal 5 ayat 2). Berdasarkan asas-asas hukum perdata tersebut di atas, khususnya asas yang termuat dalam Pasal 237 HIR / 273 RBG, maka Program Bantuan Hukum Bagi Masyarakat Tidak mampu mempunyai arti penting bagi terselenggara dan terpeliharanya prinsip-prinsip hukum dalam proses peradilan perdata. (sumber : www.badilum.info)

Pada awal perkembangan teknologi komputer, penanganan masalah peta beralih dari analog ke digital. Dengan memanfaatkan teknologi komputer tersebut dibuatlah suatu sistem informasi untuk menyajikan suatu peta yang lebih dikenal dengan Sistem Informasi Geografis (SIG). melalui peta dapat dihasilkan suatu gambaran mengenai lokasi dan informasi. Melalui peta juga dapat diambil suatu sistem keputusan.

Dalam kegiatan penyajian informasi di Pengadilan Agama dilakukan dengan terlebih dahulu mengolah data tersebut dengan menggunakan Microsoft Excel. Dari hasil pengolahan data ini kemudian dipadukan dengan menggunakan peta analog guna menentukan titik lokasi yang bersangkutan. Hal yang demikian entu saja menyebabkan kurangnya efisiensi waktu dalam penyajian 
informasi kepada pihak-pihak yang membutuhkan. Untuk memudahkan hal - hal tersebut, dirancanglah sebuah sistem baru berbasis web yang diharapkan dapat membantu mengatasi permasalahan yang ada. Sistem dirancang menggunakan notasi dari Unified Modeling Language (UML).Mengingat pentingnya peranan Rancang Bangun Sistem Informasi Pos Bantuan Hukum (Posbakum) Pada Pengadilan Agama Serang Menggunakan Gis ( Geografis Informasi Sistem ) Berbasis Web dalam hal ini, maka dibuatlah suatu penelitian dengan judul Rancang Bangun Sistem Informasi Pos Bantuan Hukum (Posbakum) Pada Pengadilan Agama Serang Menggunakan Gis ( Geografis Informasi Sistem ) Berbasis Web. Dengan harapan mampu memberikan efesiensi pembuatan gugatan dalam berperkara kepada pengguna serta menentukan lokasi pada pengadilan agama yang ingin mencari keadilan dan informasi dimanapun berada selama ada akses internet.

\section{DASAR TEORI}

\section{A. Perancangan Sistem}

Menurut Robert J.Verzello dan Jhon Reutur III, dalam Henderi (2012 :11) perancangan sistem atau desain sistem adalah :

1. Tahap setelah analisis sistem dalam pengembangan sistem.

2. Pendefinisian kebutuhan fungsional.

3. Persiapan untuk rancang bangun implementasi.

4. Menggambarkan bagaimana sistem dibentuk.

Menurut Jhon Burch dan Gary GrundNitski, : (2012 : 11) perancangan sistem adalah "penggambaran, perencanaan dan pembentukan sketsa atau pengaturan dari

beberapa elemen yang terpisah ke dalam suatu kesatuan yang utuh dan berfungsi". Sedangkan menurut J.M. Scots, perancangan sistem adalah "proses mengkonfigurasikan dari komponen perangkat lunak dan perangkat keras dari sistem". Henderi : (2012 : 11) Mengacu pada ketiga definisi tersebut diatas dapat disimpulkan bahwa perancangan sistem atau desain sistem adalah proses pengkonfigurasian dan menggambarkan elemen - elemen sistem yang ingin diterapkan atau diimplementasikan sebagai kesatuan sistem yang berjalan dan menetapkan kebutuhan fungsional yang ingin dicapai.

\section{B. Entity Relasionship Diagram}

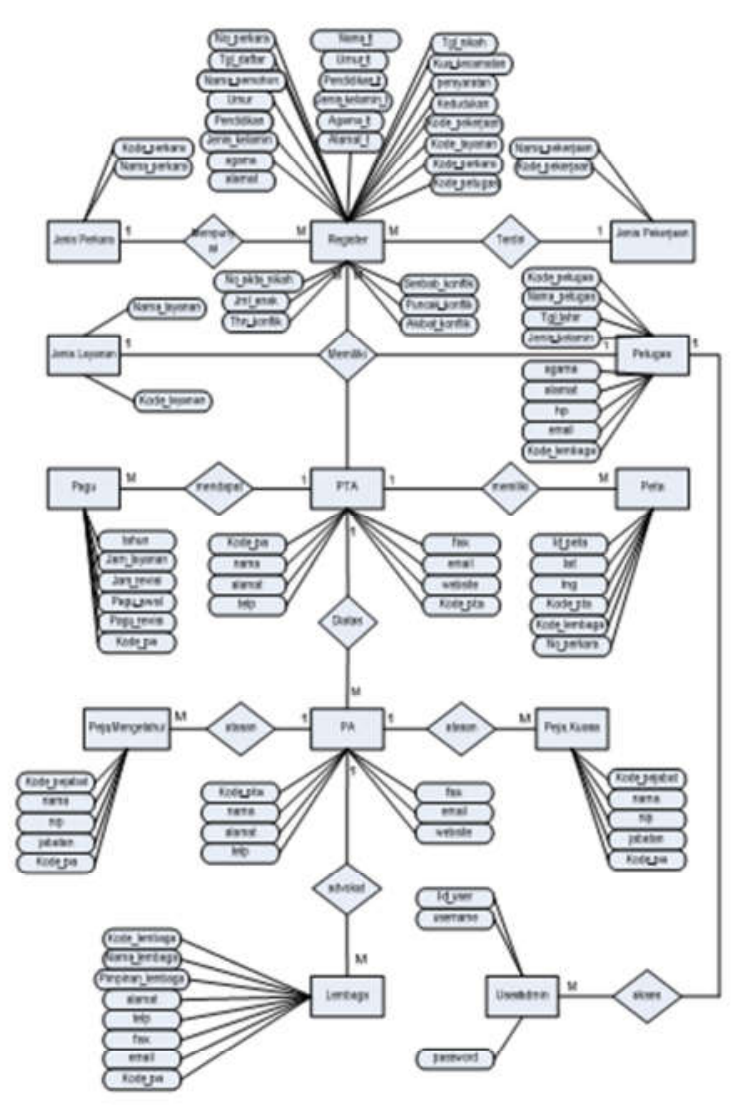

Gambar 3.102 Entity Relationship Diagram

\section{Analisis Dan PeranCANGan Sistem}

A. Perancangan Antarmuka:

Perancangan antarmuka (user interface) merupakan salah satu jenis perancangan yang igunakan untuk menggambarkan antarmuka yang akan digunakan pada pembuatan aplikasi. Perancangan antarmuka (user interface) tersebut adalah sebagai berikut : Halaman Admin Setelah admin melakukan login, maka sistem akan menampilkan halaman admin apabila User ID dan password valid. Pada halaman admin terdapat menu Data Tampil Peta, data Input Peta, Data Pendaftaran gugatan, Cetak Belangko Pendaftaran, Data Jenis perkara, Data Jenis Layanan, Data Jenis Pekerjaan, Data Petugas, Data Lembaga, Data PTA, Data PA, Data Pejabat Kuasa, Data Pejabat Mengetahui, Data Pagu Anggaran, Gerafik Perkara Masuk, Gerafik Pagu, dan Data Pengolah Administrator atau Ganti Passwordyang dapat digunakan admin untuk mengubah passwordnya. 
IV. HASIL DAN PEMBAHASAN

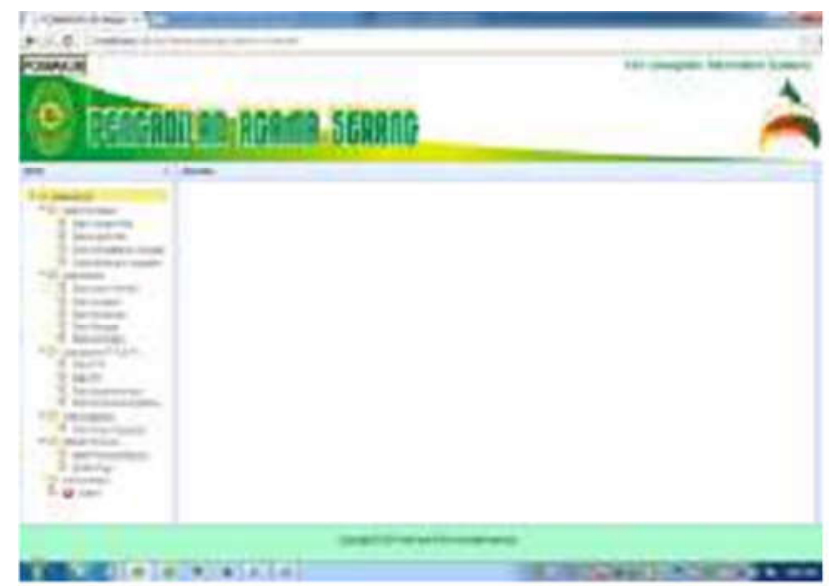

Gambar 4.22 Halaman Admin

\section{Halaman Tampil Peta Lokasi}

Halaman Tampil Peta Lokasi Posbakum pada setiap satker memberikan informasi lokasi posbakum, alamat setiap satker, kepada para pencari keadilan terdapat icon perkara yang memberikan informasi apabila kita klick.

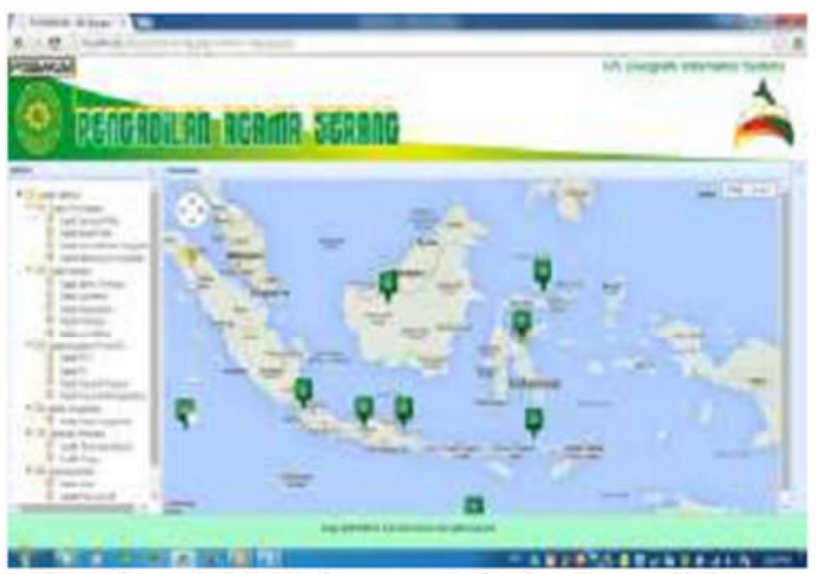

Gambar 4.23 Halaman Admin Tampil Peta Lokasi

\section{KESIMPULAN}

1. Membangun Rancang Bangun Sistem Informasi Pos Bantuan Hukum (POSBAKUM) pada Pengadilan Agama Serang Menggunak Gis (Geografis Information System) Berbasis Website, yang dilengkapi dengan beberapa kelebihan, yaitu para pencari keadilan bisa melihat lokasiwilayah dalam suatu satker dan satker mana saja yang sudah menyediakan (POSBAKUM) Posbantuan Hukum di setiap sateker, secara online. Selain itu, dengan adanya fasilitas layanan Pos Bantuan Hukum
Para Perkara Bisa Membuat Blangko Gugatan Sendiri dengan menginput data yang sudah di sediakan dalam aplikasi ini sehingga mempercepat pekerjaan tanpa menunggu pembuatan gugatan, para Perkara juga dapat memperoleh informasi mengenai POSBAKUM dimana saja dan kapan saja tanpa harus datang langsung ke kantor Setiap Satker yang telah menyediakan.

2. Pada sistem tersebut dilengkapi dengan informasi peta lokasi POSBAKUM sehingga ini akan menjadi suatu nilai lebih bagi satker untuk mempercepat suatu pekerjan, akan tetapi tetap dapat menekan biaya yang dikeluarkan.

3. Dengan adanya fasilitas proses pengelolaan data, akan memudahkan staff pengelola dta (admin) dalam menyimpan dan pencarian data ketika dibutuhkan kembali.

4. pembuatan laporan secara otomatis di dalam sistem informasi POSBAKUM ini dapat membantu manajemen SATKER (Satuan Kerja Pengadilan Agama Serang) dalam mengevaluasi kinerja dan perkembangan peradilan.

\section{DAFTAR PUSTAKA}

[1] Muhammad Zainal, (2011), Pengertian Pemetaan Geografis (Pemakaian Kompas Dalam Pemetaan), pada tanggal 23 Juni 2014 pukul 16.15 WIB, diakses di http://www.masbied.com/2011/09/24/pengertianpemetaan-geologi-pemakaian kompas-dalam-pemetaan/

[2] Eka (2011), Sistem Informasi Geografis Berbasis Web Untuk Pemetaan Pariwisata Kabupaten Gianyar, Universitas Pembangunan Nasional "Veteran", Yogyakarta. pada tanggal 3 Juli 2014 pukul 13.14 WIB diakses

di ttp://repository.upnyk.ac.id/905/1/SKRIPSI.pdf

[3] Faizah, Lailatul, (2011), Sistem Informasi Geografis Maktab Pada Pelaksanaan Ibadah Haji, Universitas Islam Negeri Malang, Malang. pada tanggal 24 Juni 2014 pukul 13.14 WIB,diakses di http://lib.uinmalang.ac.id/thesis/introduction/05550128lailatul-faizah.ps

[4] Fathansyah, (2007), Buku Teks Komputer Basis Data, Informatika, Bandung. Google Earth (2014)

[5] Hendri, (2012), Perancangan Sistem informasi, Serang, CV Caya Minolta.

[6] Hakim, Lukman, 2006, “ Pengenalan Internet “, Graha Ilmu, Yogyakarta.

[7] Indah, (2009), Sistem Informasi Geografis Fasilitas Kota Bogor Menggunakan Framework Pmapper, Institut Pertanian Bogor, Bogor pada tanggal 23 Juni 2014 pukul 13.14 WIB, diakses di http://repository.ipb.ac.id/bitstream/handle/123456789/1 3023/G09ika.pdf?sequence $=10$

[8] Murdiyanto, (2010), Simulasi Daerah Banjir Menggunakan Sistem Informasi Geografis Di Kabupaten Sragen, Universitas Islam Negeri Malang, Malang. , pada tanggal 25 Juni 2014 pukul 13.14 WIB, diakses di http://lib.uin- 